\title{
Towards a Volumetric Variation of Lake Kivu Gases by the Nyamulagira and Nyiragongo Volcanoes
}

\author{
Mapendano Yalire1, Bahati Rusimbuka1, Musosekania Kasereka1, Laurent Bizimungu1, \\ Augusta Mutoni², Gaëtan Sakindi², Katcho Karume ${ }^{1,3}$ \\ ${ }^{1}$ Goma Volcano Observatory, Department of Geochemistry and Environment, Democratic Republic of Congo \\ ${ }^{2}$ Lake Kivu Monitoring Program (LKMP), Energy Development Corporation Limited (EDCL), Rwanda \\ ${ }^{3}$ Evangelical University in Africa, Faculty of Agronomy and Environment Bukavu, Democratic Republic of Congo \\ Email: *yaliremat@yahoo.fr
}

How to cite this paper: Yalire, M., Rusimbuka, B., Kasereka, M., Bizimungu, L., Mutoni, A., Sakindi, G., \& Karume, K. (2022). Towards a Volumetric Variation of Lake Kivu Gases by the Nyamulagira and Nyiragongo Volcanoes. Journal of Geoscience and Environment Protection, 10, 1-9. https://doi.org/10.4236/gep.2022.102001

Received: November 26, 2021

Accepted: February 5, 2022

Published: February 8, 2022

Copyright $\odot 2022$ by author(s) and Scientific Research Publishing Inc. This work is licensed under the Creative Commons Attribution International License (CC BY 4.0).

http://creativecommons.org/licenses/by/4.0/

\begin{abstract}
After the volcanic eruption of January $17^{\text {th }}, 2002$, Goma Volcano Observatory (OVG) initiated carbon dioxide $\left(\mathrm{CO}_{2}\right)$ monitoring in the fractures south of the Nyiragongo volcano and at the northern edge of Lake Kivu. During the period from March $17^{\text {th }}, 2017$ to June $10^{\text {th }}, 2020$, twice a week, a GA 5000 gasometer was used for $\mathrm{CO}_{2}$ in the fractures as well as in the mazukus, respectively, as part of a project funded by the Kingdom of the Netherlands through the Lake Kivu Monitoring Program (LKMP) in Rwanda. The level of volcanic activity was determined by the volume of gas emitted by the volcano and measured by a DOAS and the seismicity measured by a network of 15 seismometers managed by the OVG. The results show that the concentration of $\mathrm{CO}_{2}$ in the active fractures from recent Nyiragongo eruptions varies with volcanic activity and the occurrence of a large earthquake in the East African Rift; but in the mazukus there is almost no relationship between $\mathrm{CO}_{2}$ content and volcanic activity. The study also shows that the influence of carbon dioxide in mazukus on the carbon dioxide into the Lake Kivu waters remains a major research question. The purpose of this study is to establish the relationship between the existing Carbon Dioxide (mazukus) in the Northern watershed and that of the deep waters of Lake Kivu.
\end{abstract}

\section{Keywords}

Mazuku, Carbon Dioxide, Lake Kivu, Nyiragongo Volcano

\section{Introduction}

Seven hundred million people in the world live under the permanent threat of a 
volcano, most of them in high density areas (Coulais et al., 2004).

The lava lake of Nyiragongo volcano was born five months after its January $17^{\text {th }} 2002$ eruption, in May 2002, and highlighted in November 2002 (OVG, 2002). Since then, the plume of gas from the volcano has been polluting the environment on a daily basis, generating acid rain and deposits that probably feed the waters of the rivers and Lake Kivu located about $18 \mathrm{~km}$ to the south (Yalire et al., 2010).

Indeed, the harmful gases contained in this plume can be the reason for several diseases in humans, animals and even cause environmental destruction. Contamination occurs as a result of the absorption of ash and hair from Pele containing harmful elements as well as gases that pollute the atmosphere. These various volcanic products are capable of attacking the human respiratory tract, causing asthma, eye irritation (conjunctivitis), skin diseases (dermatitis), diarrhoea, etc. (Hansell \& Oppenheimer, 2004).

Haroun Tazieff has long believed that the study of volcanic gases was an important key, if not among the principal keys, to understanding the mechanisms of eruptions and especially to predicting them. During an eruption, fluids often precede solids and are therefore "warning signs".

Therefore, it would be important to control the threat from volcanic gases in the region. It depends mainly on the type of gas and its toxicity and concentration. Since a volcano releases several types of gas, especially volcanoes that are permanently active such as Nyiragongo and Nyamulagira, the gases that affect the health of the population and are therefore harmful should be studied in depth (Cuoco et al., 2013).

On the other hand, fresh fractures from the eruptions of Nyiragongo volcano contain Carbon Dioxide $\left(\mathrm{CO}_{2}\right)$ whose concentration varies in relation to the volcanic activity (Yalire et al., 2010). These fractures run along the flanks, but those in the south cross the city of Goma and plunge into Lake Kivu. The same is true of ancient fractures visible only towards the northern shore of the lake, where the various $\mathrm{CO}_{2}$ exit points called mazukus are located. The concentration of carbon dioxide in these points is too high but varies too little and does not seem to have a direct relationship with the activity of the volcanoes as it's the case for the active fractures of Nyiragongo (Yalire et al., 2010). Some mazukus are detectable on the old fractures at the fronts of the lava flows, on the other hand, other fractures are completely covered by flows (Smets et al., 2009).

Thus, the northern watershed of Lake Kivu constitutes a large reservoir of carbon dioxide from which gas-rich infiltrated rainwater feeds the deep waters of Lake Kivu through subaqueous springs (Schmid et al., 2004). This lake currently contains 300 cubic kilometers of carbon dioxide and 60 cubic kilometers of methane, which can rise through volcanic vents, which is more than 300 times the volume of gas contained in the waters of Lake Nyos, which caused 1,700 deaths when it erupted (Le lac Kivu menace ses riverains', Courrier international (Afrique Centrale, 2009)). 
Also, surface and deep waters never mix because of the depth of the lake and its low exposure to winds, preventing convection. At present, the surface waters, although colder, are indeed less rich in salts than the deep waters (Schmid et al., 2005).

Deep waters are about $2^{\circ} \mathrm{C}$ warmer than surface waters, but they are much richer in salt (up to 6 grams per litre). This salt richness affects the density of the water and considerably increases the energy required to cause complete mixing of the lake waters (Descy, 2012).

The gases from Lake Kivu have been clearly studied by several cited authors. The same is true of the gases in the mazukus towards the northern edge of Lake Kivu. However, a proper relationship between these two aspects has been elucidated. The study verifies whether the gas from the northern watershed of Lake Kivu which constitutes also the southern part of Virunga active volcanoes really influences the enormous volume of gas located in the deep waters of Lake Kivu.

\section{Materials and Methodology}

In this study, a British-made GA 5000 gasometer with an accuracy level of $0.03 \%$ was used, with a metal probe connected to the gasometer by a plastic casing approximately $10 \mathrm{~mm}$ in diameter. The principle consists of introducing the probe into the ground and sucking the gases through the gasometer.

The numerical values of the volume of different gases contained in the soil such as carbon dioxide $\left(\mathrm{CO}_{2}\right)$, methane gas $\left(\mathrm{CH}_{4}\right)$, hydrogen sulphide $\left(\mathrm{H}_{2} \mathrm{~S}\right)$, carbon monoxide $(\mathrm{CO})$, oxygen $\left(\mathrm{O}_{2}\right)$ are displayed on the gasometer screen. Several field trips were made for several reasons. Firstly, the sites are extremely numerous and run from Goma to Sake covering a distance of about $27 \mathrm{~km}$. Secondly, each site should be monitored twice a month to ensure that the concentration of gas in the mazukus as well as in the active fractures did not vary. Measurements were made every fortnight in the mazukus and every week in the active fractures.

The value of carbon dioxide $\left(\mathrm{CO}_{2}\right)$ attracted attention as its volume is very high in the mazukus (Kasereka, 2017) and the same gas is found in Lake Kivu at a considerable volume (Schmid et al., 2005).

The concentration of other gases is too random in the different sites surveyed at the northern edge of Lake Kivu while the volumes of methane gas $\left(\mathrm{CH}_{4}\right)$ and hydrogen sulphide $\left(\mathrm{H}_{2} \mathrm{~S}\right)$ are very high in the lake waters.

Sixty-five sites with a carbon dioxide concentration greater than or equal to $10 \%$ in the north near Lake Kivu were used in this study as can be seen on the map below. All recorded data were encoded in an Excel file for processing.

Using the results obtained in previous work, the carbon (C) isotopic signature in both mazukus (on land) and in the water of Lake Kivu was used to check for some correlation that could lead to the conclusion whether the source of carbon in mazukus (Figure 1) is the same as that in Lake Kivu.

The map shows that all the mazuku sites are mainly located not far from the 


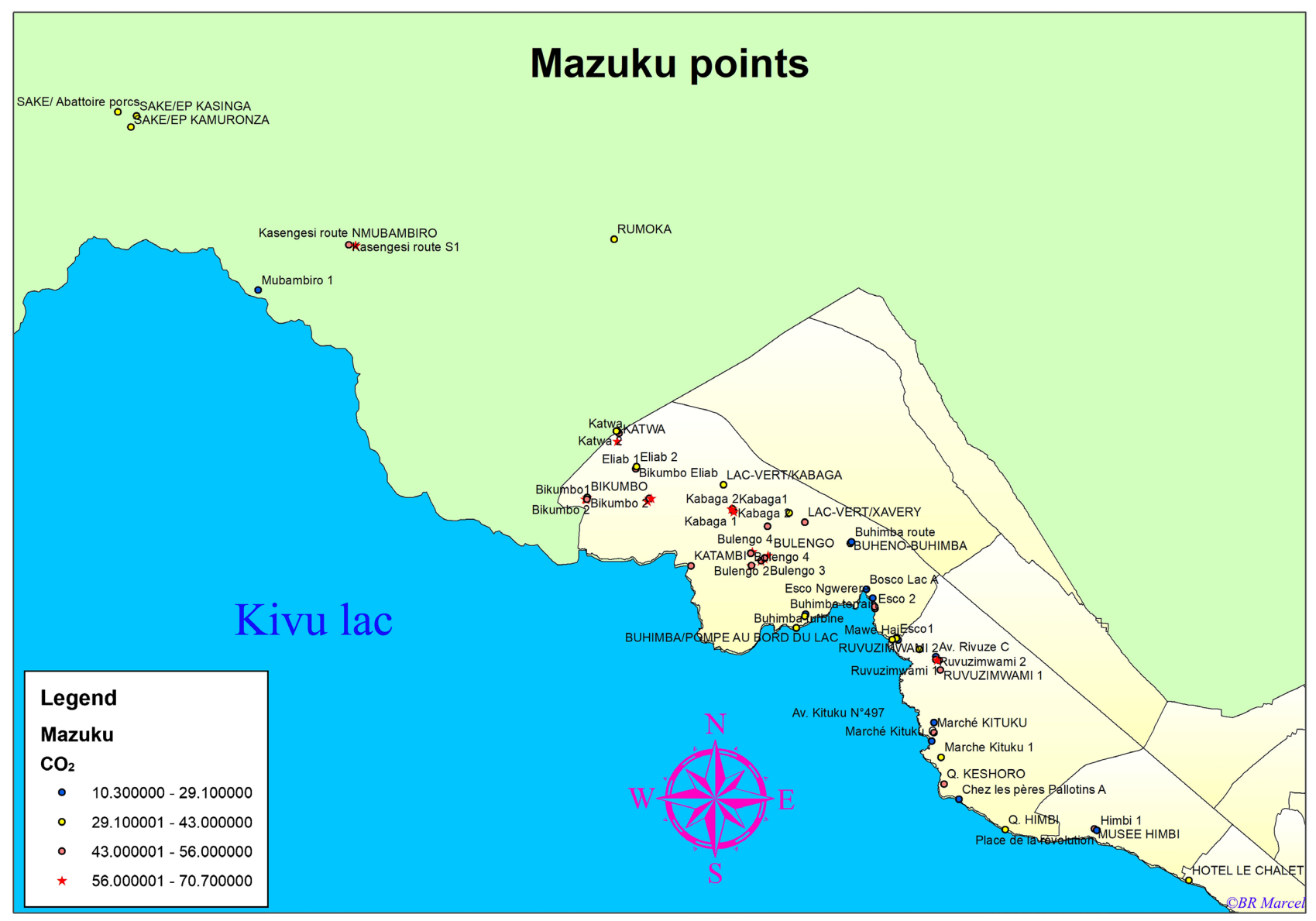

Figure 1. Location map of the Mazukus.

northern coast of Lake Kivu and on the fronts of the lava flows as the direction of the lava flows are North-South.

So we can see why there is a lot of bicarbonate in the deep waters of the lake because the $\mathrm{CO}_{2}$ from the mazukus enters as aqueous $\mathrm{CO}_{2}$ and not as $\mathrm{CO}_{2}$ gas. Meanwhile, the surface waters of Lake Kivu are almost devoid of $\mathrm{CO}_{2}$.

\section{Results and Discussion}

It should be considered that theoretically during the water-gas contact (i.e. rainwater from the northern catchment of Lake Kivu that infiltrates is brought into contact with the $\mathrm{CO}_{2}$ gas of the mazukus (as shown in Figure 2) to become aqueous $\mathrm{CO}_{2}$. This aqueous carbon dioxide reacts with water to form carbonic acid $\left(\mathrm{H}_{2} \mathrm{CO}_{3}\right)$ which in turn reacts to form the carbonate ion $\mathrm{CO}_{3}^{2-}$ and the hydrogen carbonate ion or bicarbonate ion $\mathrm{HCO}_{3}^{-}$.

\subsection{Mazukus Carbon Dioxide Data Used}

From the above the graphe, it is worth noting that the highest concentration of carbon dioxide was observed at the Bulengo site with $70.7 \% \mathrm{CO}_{2}$ by volume; followed by Bikumbo 1 and Bikumbo 2 with $69.3 \%$ and $69.1 \% \mathrm{CO}_{2}$ by volume respectively (see Figure 2). These values did not vary significantly throughout the 
study period. This confirms previous works on mazukus such as (Smets et al., 2009; Yalire et al., 2010).

\subsection{Active Fractures}

Looking at the graphs of Figure 3, it can be seen that the measurements in the active fractures at Bugarura 1, 2, 3 and 4 and Munigi respectively give values that fluctuate at any given time. However, at Bugarura, the periods from April to October 2018 and from the end of May to October 2019 show a substantial increase in carbon dioxide concentration, periods that most often correspond to the increase in activity in the central crater of Nyiragongo volcano.

On the other hand, on the active fracture at Munigi, the graph of Figure 4

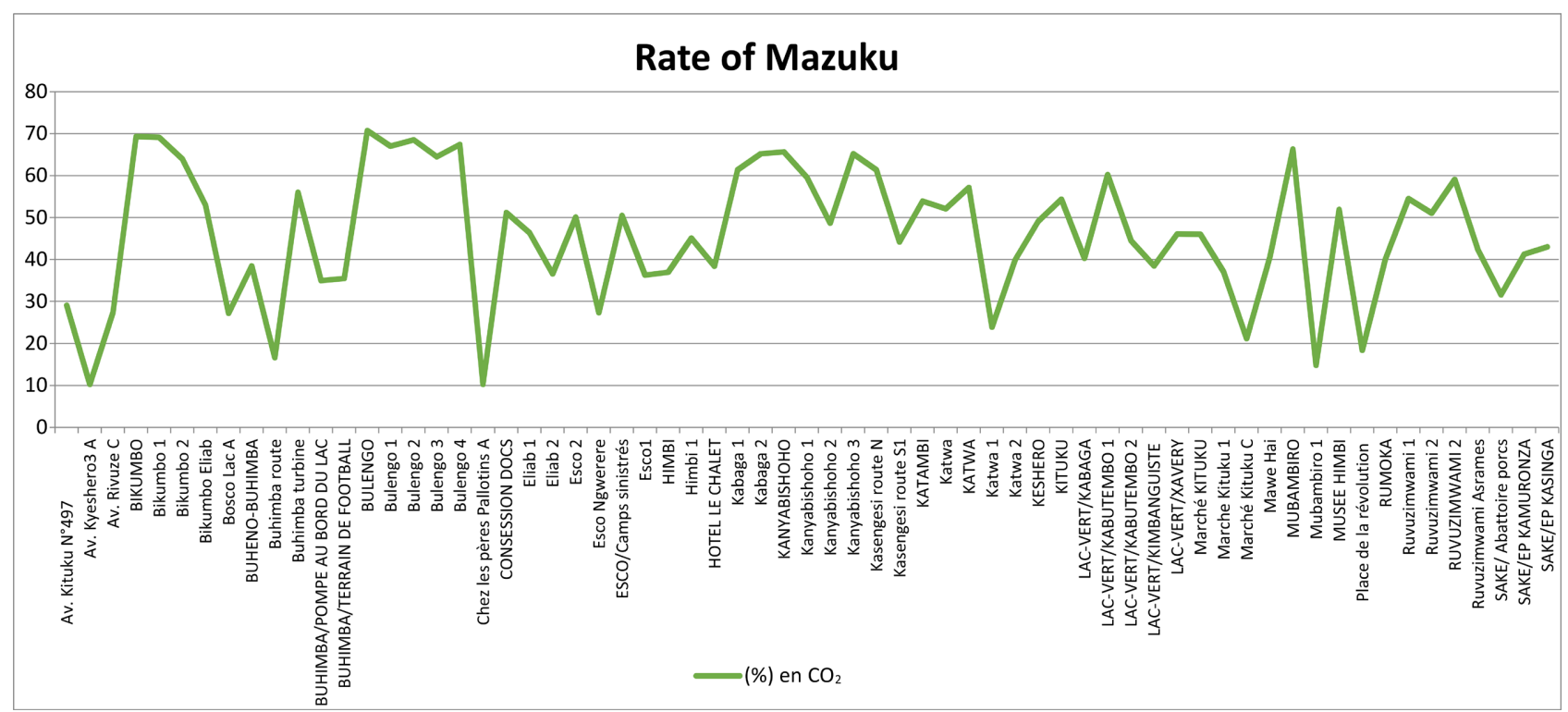

Figure 2. Rate of $\mathrm{CO}_{2}$ in different sites of Mazukus.

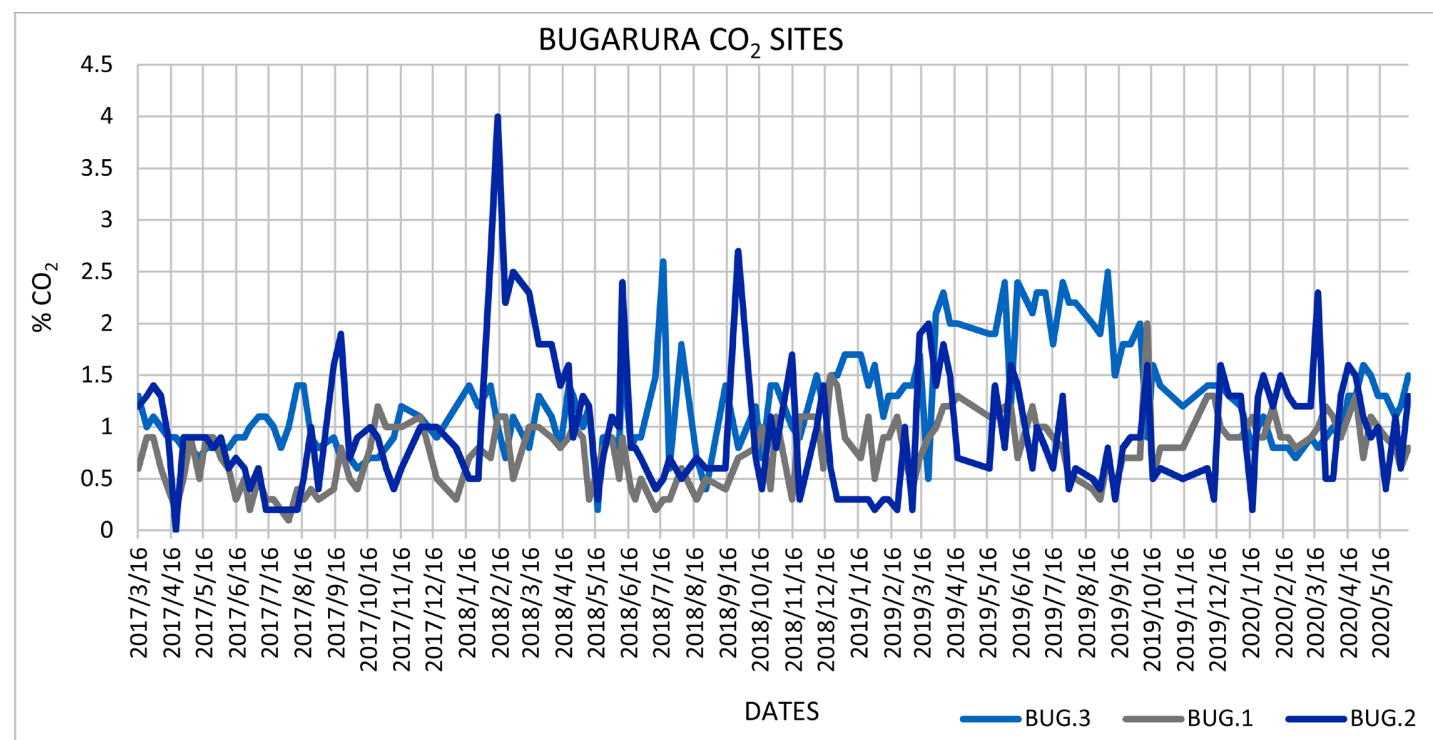

Figure 3. Bugarura sites $\mathrm{CO}_{2}$ variation. 


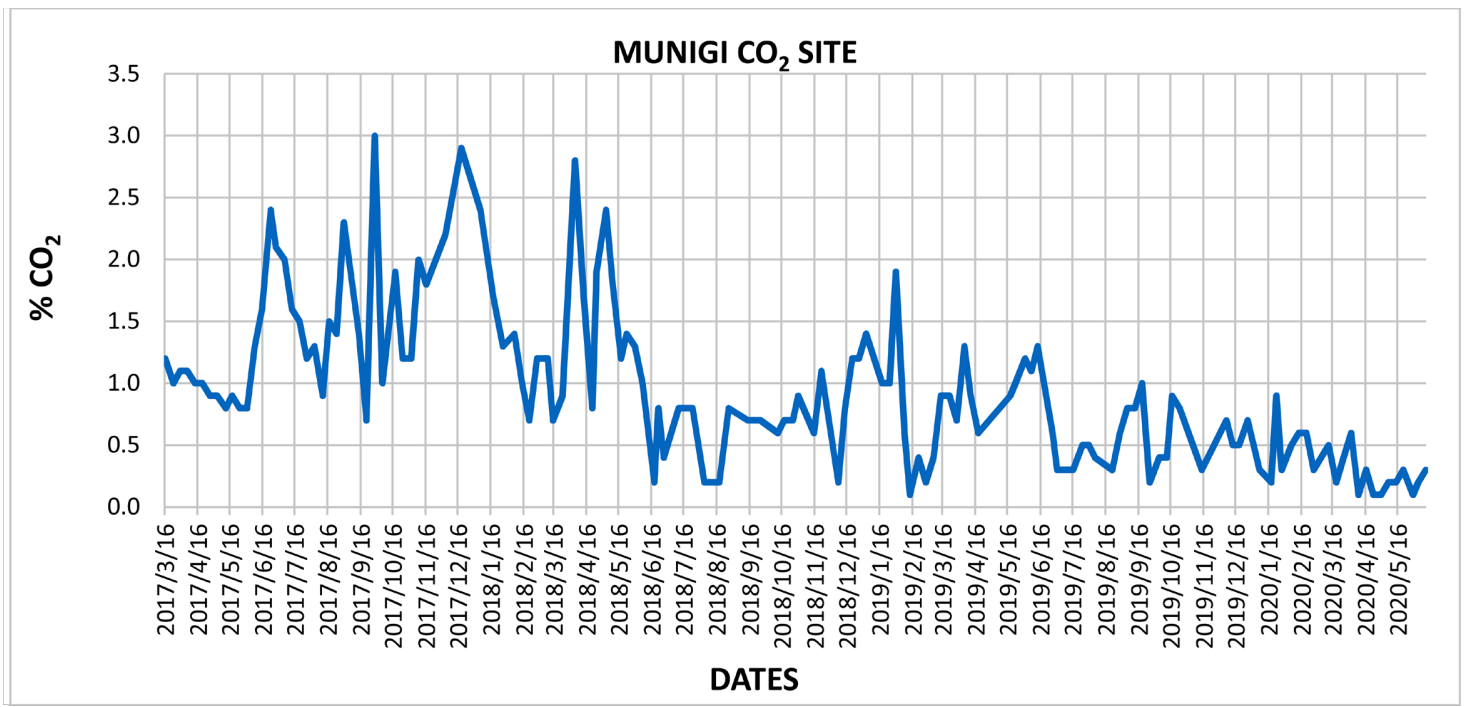

Figure 4. Munigi site $\mathrm{CO}_{2}$ variation.

shows a clear variation of the carbon dioxide content respectively during the periods from $01 / 06 / 2017$ to $31 / 05 / 2018$; from $26 / 10 / 2018$ to 13/06/2019 and from $22 / 08 / 2019$ to $12 / 03 / 2020$. These variations are very important because they sufficiently show a certain correlation with the different periods of activity of the active volcanoes of Virunga, especially that of Nyiragongo. The fading of the curve would mean a significant decrease in the activity of the Nyiragongo lava lake.

\subsection{Isotopic Signature}

For Frédéric Bruneut b, 2007 the fractionation between $\mathrm{CO}_{2}$ gas and aqueous $\mathrm{CO}_{2}$ is as follows: $\varepsilon \mathrm{CO}_{2}$ gas (aqueous $\left.\mathrm{CO}_{2}\right)=(0.0049 \pm 0.0015) \times \mathrm{T}-1.31 \pm$ $0.005-1.29-1.19$. This fractionation is caused by the difference in the diffusion coefficients of two carbon atoms $\left({ }^{12} \mathrm{C}\right.$ and $\left.{ }^{13} \mathrm{C}\right)$.

According to Davidson (1995), this fractionation can be smaller and depends on the initial $\mathrm{CO}_{2}$ signature of the soil. With the weathering of rocks and contact with surface water, $\mathrm{CO}_{2}$ will percolate into the soil and form carbonic acid. This acid then participates in the weathering of the rocks. $\mathrm{CO}_{2}+\mathrm{H}_{2} \mathrm{O}=\mathrm{H}_{2} \mathrm{CO}_{3}$

A few years later, several studies (Blavoux, 2004; Rightmire \& Hanshaw, 1973; Fritz et al., 1978; Parada et al., 1983) used the $\delta^{13} \mathrm{C}$ of soil $\mathrm{CO}_{2}$ to understand the isotopic evolution of dissolved $\mathrm{CO}_{2}$ in the groundwater system.

However, allochthonous carbon has an isotopic signature that depends on the vegetation present in the basin. It therefore varies between $-26 \%$ and $-12 \%$ depending on the proportion of plants present.

For carbon of autochthonous origin, the $\delta^{13} \mathrm{C}$ depends on the isotopic signature of $\mathrm{CO}_{2}$. Indeed, during photosynthesis of phytoplankton, a fractionation of the order of $20 \%$ occurs. Therefore, considering that $\mathrm{CO}_{2}$ in the carbon cycle and the isotopic compositions of carbon reservoirs, surface waters is of the order of $-10 \%$ and therefore the isotopic signature of the organic matter produced is 
of the order of $-30 \%$.

But according to (Tedesco et al. 2010), the $\delta^{13} \mathrm{C}-\mathrm{CO}_{2}$ in mazukus from the northern edge of Lake Kivu varies from

$-6.76 \%$ o to $-5.29 \%$. In contrast, the $\delta^{13} \mathrm{C}-\mathrm{CO}_{2}$ of dissolved gas samples in the main basin of Lake Kivu varies between $-5.43 \%$ and $-5.60 \%$ for a depth varying between 320 and $475 \mathrm{~m}$.

In the Gulf of Kabuno basin, the value is $-10.29 \%$ o thus different from that found in the mazukus.

From the isotopic data recorded by the various authors, it should be concluded that the origins of $\mathrm{CO}_{2}$ in Lake Kivu, the Gulf of Kabuno and mazukus are apparently different. The isotopic value of $\mathrm{CO}_{2}$ in the waters of Lake Kivu varies between $-5.43 \%$ and $-5.60 \%$ at a great depth but does not give an idea of the isotopic value for surface waters which are in contact with the areas covered by mazukus. This means that we can maintain the hypothesis according to which the $\mathrm{CO}_{2}$ of the northern watershed of Lake Kivu infiltrates directly lower not as gas but rather as biocarbonate ion associating with the deep waters of this lake.

\section{Conclusion}

The northern rim of Lake Kivu remains a carbon dioxide rich area mainly from mazukus lodged on ancient fractures, most of which were located on the flow fronts. These flows were visibly north-south in a direction towards Lake Kivu. This area covered by the southern slopes of the volcanoes is a huge reservoir of carbon dioxide which is first transformed into bicarbonate ions before feeding the deep waters of the northern part of the Lake. The carbon isotopic signature of the carbon dioxide from the mazukus shows an apparent difference compared to that of the carbon dioxide from the deep waters of Lake Kivu in its northern part.

The active fractures, i.e. those linking the active Virunga volcanoes to Lake Kivu, do not appear to be feeding carbon dioxide into the lake at the moment, given the minimal values recorded. These carbon dioxide concentration values lead to a decrease in the graphs to show that the current activity of the Nyiragongo volcano is decreasing.

Globally, the isotopic values of carbon dioxide in the mazukus, lake Kivu and the Gulf of Kabuno almost do not match. It is, therefore, curious to note that the surface waters of Lake Kivu do not undergo a significant influence of Carbon Dioxide $\left(\mathrm{CO}_{2}\right)$ from mazukus. A more in-depth study remains useful in order to be able to compare the isotopic values of $\mathrm{CO}_{2}$ in deep lake waters with those of $\mathrm{CO}_{2}$ in surface waters. This is very important as this study would allow us to draw definitive conclusions.

\section{Conflicts of Interest}

The authors declare no conflicts of interest regarding the publication of this paper. 


\section{References}

Afrique Centrale (2009). Le lac Kivu menace ses riverains. Courrier International.

Blavoux, B., Gourcy, L., \& Chéry, L. (2004). L’utilisation des isotopes pour caractériser l'origine des pollutions dans les eaux souterraines. Société géologique de France, 9-14.

Rightmire, C. T., \& Hanshaw, B. B. (1973). Relationship between the Carbon Isotope Composition of Soil $\mathrm{CO}_{2}$ and Dissolved Carbonate Species in Groundwater. Water Resources Research, 9, 958-967. https://doi.org/10.1029/WR009i004p00958

Tedesco, D., Tassi, F., Vaselli, O., Poreda, R. J., Darrah, T., Cuoco, E., \& Yalire, M. M. (2010). Gas Isotopic Signatures (He, C, and Ar) in the Lake Kivu Region (Western Branch of the East African Rift System): Geodynamic and Volcanological Implications. Journal of Geophysical Research: Solid Earth, 115, Article No. B01205. https://doi.org/10.1029/2008JB006227

Cuoco, E., Tedesco, D., Poreda, R. J. et al. (2013). Impact of Volcanic Plume Emissions on Rainwater Chemistry during the January 2010 Nyamuragira Eruptive Event: Implications for Essential Potable Water Resources. Journal of Hazardous Materials, 244-245, 570-581. https://doi.org/10.1016/j.jhazmat.2012.10.055

Hansell, A., \& Oppenheimer, C. (2004). Heath Hazards from Volcanic Gases: A Systematic Literature Review. Archives of Environmental Health, 59, 628-639. https://doi.org/10.1080/00039890409602947

Coulais, J.-F., Gentelle, P., Marin, B., \& Vallat, C. (2004). Naples: Le Vésuve et Pompéi. Belin.

Descy, J.-P., Darchambeau, F., Schmid, M., \& Research Unit in Environmental and Evolutionary Biology (2012). Lake Kivu: Limnology and Biochemistry of a Tropical Great Lake. Springer. https://doi.org/10.1007/978-94-007-4243-7

Kasereka, M. M., Yalire, M. M., Minani, A. S., Samba, C. V., Bisusa, A. K., Kamate, E. K., Mashagiro, N., Syauswa, M., \& Kavuke, J. K. (2017). Risk Associate with Mazuku in the Goma Area, Democratic Republic of the Congo (East Africa Rift). Journal of Water and Environmental Sciences, 1, 164-174.

Observatoire Volcanologique de Goma (OVG) (2002). Rapport Mois de Novembre. Observatoire Volcanologique de Goma.

Parada, C. B., Long, A., \& Davis, S. N. (1983). Stable Isotopic Composition of Soil Carbon Dioxide in the Tucson Basin, Arizona, U.S.A. Chemical Geology, 41, 279-236. https://doi.org/10.1016/S0009-2541(83)80020-5

Fritz, P., Reardon, E. J., Barker, J., Brown, R. M., Cherry, J. A., Killey, R. W. D., \& McNaughton, D. (1978). The Carbon Isotope Geochemistry of Small Groundwater System in Northeastern Ontario. Water Resources Research, 14, 1059-1068. https://doi.org/10.1029/WR014i006p01059

Reardon, E. J., \& Langmcjih, D. (1974). Thermodynamic Properties of the Ion Pairs $\mathrm{MgCO}_{3}$ and $\mathrm{CaCO}_{3}$ from 1 to $50^{\circ} \mathrm{C}$. American Journal of Science, 278, 179-216. https://doi.org/10.2475/ajs.274.6.599

Schmid, M., Tietze, K., Halbwachs, M., Lorke, A., McGinnis, D., \& Wüest, A. (2004). How Hazardous Is the Gas Accumulation in Lake Kivu? Arguments for a Risk Assessment in Light of the Nyiragongo Volcano Eruption of 2002. Acta Vulcanologica, 14/15, 115-121.

Schmid, M., Halbwachs, M., Wehrli, B., \& Wëst, A. (2005). Weak Mixing in Lake Kivu: New Insights Indicate Increasing Risk of Uncontrolled Gas Eruption. Geochemistry, Geophysics, Geosystems, 6, Article No. Q07009.

https://doi.org/10.1029/2004GC000892 
Smets, B., Tedesco, D., Kervyn, F., Kies, A., Vaselli, O., \& Yalire, M. M. (2009). Dry Gas vents ("Mazuku") in Goma Region (North-Kivu, Democratic Republic of Congo): Formation and Risk Assessment. Journal of African Earth Sciences, 58, 787-798. https://doi.org/10.1016/j.jafrearsci.2010.04.008

Yalire et al. (2010). Quelques considérations sur la qualité des eaux consommées dans les villages voisins de la ville de Goma in Cahiers du CERUKI. Nouvelle Série, 40, 191-197. 